Грень Л.М., д.держ.упр., доц., НТУ «ХПІ», м. Харків, ORCID: 0000-0003-4466-6018,

Чеботарьов М.К., к.пед.н., НTУ «ХПI», м. Харків, ORCID: ORCID:0000-0002-3915-7705

Hren L., Doctor of sciences in Public Administration, Associate Professor, Professor of the department of pedagogy and psychology of social systems management, National technical university "Kharkiv polytechnic institute", Kharkiv,

Chebotarev M., candidate of pedagogic sciences, Associate Professor of the department of pedagogy and psychology of social systems management, National technical university "Kharkiv polytechnic institute", Kharkiv

\title{
ВПЛИВ ФІЛОСОФСЬКО-УПРАВЛНСЬКИХ ФАКТОРІВ НА ФОР- МУВАННЯ АТРИБУТИВНИХ РИС СУЧАСНОГО КЕРІВНИКА
}

\section{THE IMPACT OF PHYLOSOPHICAL AND MANAGERIAL FACTORS ON ATTRIBUTIVE FEATURES FORMATION IN A CONTEMPORARY MANAGER}

У статті визначено, що філософія управління є системою поглядів керівника на сенс і призначення його діяльності, щуо означає глобальний погляд керівника на свою професію і професійну діяльність у всіх ї̈ аспектах; підкреслено, щзо філософія державного управління сфокусована на ставленні людини до світу, ї̈ участі у державному управлінні; на підставі проведеного дослідження визначено 10 топових рис сучасного керівника, який прагне до мудрого управління; доведено, щуо здійснювати функиї управління повинні керівники, які у своій діяльності керуються мудрим управлінням; розкрито взаємозв'язок між набором атрибутивних рис сучасного керівника, який прагне до філософії управління, і викликами мінливого середовища.

Ключові слова: державна кадрова політика, філософія державного управління, філософія управління, сучасний керівник, атрибутивні риси.

It is determined in the article that management philosophy is a system of a manager's views on the sense and the destination of his/her activity and professional responsibility in all its aspects; it is accentuated on state management philosophy being focused on a person's attitude to the world, their participation in public management; on the grounds of the carried out research, 10 top attributes of a contemporary manager aspiring to the wise management have been determined; it is proved that managerial functions are to be performed by managers who are guided by wise management in their activities; the link between the set of attributive features in a contemporary manager striving for applying the management philosophy and the challenges of ever changing environment is disclosed.

Key words: the personnel policies of the state, public management philosophy, philosophy of management, contemporary manager. Attributive features. 
Постановка проблеми в загальному вигляді. Метою державної кадрової політики є забезпечення всіх сфер життєдіяльності держави кваліфікованими кадрами, необхідними для реалізації національних інтересів у контексті розвитку України як демократичної, соціальної держави з розвинутою ринковою економікою. Серед основних цілей реалізації державної кадрової політики є відновлення технології добору кадрів для зайняття управлінських посад із числа працівників, що мають досвід роботи на посадах нижчого рівня у відповідній сфері діяльності; формування дієвого кадрового резерву на зайняття керівних посад у сферах державного управління; посилення вимог до моральних якостей осіб, які залучаються до управлінської діяльності, з метою уникнення можливих проявів корупції, запобігання виникненню конфлікту інтересів, удосконалення процедури дисциплінарного провадження [11].

Аналіз останніх досліджень і публікацій. У наукових дослідженнях вітчизняних вчених висвітлюються різні аспекти формування кадрової політики в Україні. Механізмами формування кадрової політики опікуються Т. Витко [1], С. Гончар [2], Л. Грень [3], С. Домбровська [7], О. Дороніна [8], Я. Казюк [9], Ю. Ковбасюк [4], О. Оболенський [4], С. Серьогін [4], С. Тарасов [11] та інші. Проте недостатньо розробленим залишається питання впливу філософсько-управлінських факторів на формування атрибутивних якостей сучасного керівника, здатного до реалізації національних інтересів України як демократичної, соціальної держави з розвинутою ринковою економікою.

Постановка мети. Метою статті $\epsilon$ визначення впливу філософськоуправлінських факторів на формування атрибутивних якостей сучасного керівника.

Виклад основного матеріалу дослідження. Процеси глобалізації, нестабільність економічної ситуації в країні і світі, «підвищення вимог ринку праці до кваліфікації фахівців, суперництво між суб'єктами господарювання» «потребують безупинного пошуку нових, більш досконалих форм і способів діяльності» $[14$, с.1], тому у процесі розвитку нової економічної системи значення філософії управління як специфічної галузі прикладної філософії стає все більш вагомим.

Науковці визначають філософію управління як «систему узагальнюючих суджень філософського характеру про предмет і методи управління, їх місце серед інших наук і в системі наукового знання в цілому, пізнавальній i соціальній ролі управління в сучасному суспільстві» [6].

Філософія управління, охоплюючи онтологічні питання феномену управління, є системою поглядів керівника на сенс і призначення його діяльності, що означає глобальний погляд керівника на свою професію і професійну діяльність у всіх іiі аспектах [10]. Головним суб'єктом і об'єктом управлінської діяльності є людина, іiї творчість, компетентність, професіоналізм, майстерність. Саме тому управлінські дії спрямовані на врахування всієї багатоманітності психологічних факторів, які виникають в управлінському процесі $[15$, с. 50$]$. 
«Філософія державного управління сфокусована на ставленні людини до світу, на формах, способах даності об'єкта суб'єкту чи суб'єкта суб'єкту в рамках професійної діяльності - участі у державному управлінні» [13, с. 10].

Слушною вважаємо думку науковців на чолі з Князєвим стосовно того, що завданням філософії державного управління $\epsilon$ вироблення власного відношення, ставлення до світу суб'єкта державного управління та осіб, які уповноважені на виконання державного управління як за умов кризових станів суспільства, так і у повсякденному житті [13, с. 10]. Для повноти досліджуваної проблеми вважаємо за необхідне навести визначення управлінського рішення, що «є розробленим і прийнятим, а також формально зафіксованим проектом соціальних змін. Тому кожне управлінське рішення виступає актом здійснення управлінських впливів, засобом вираження, а також способом регулювання управлінських відносин у конкретно-історичних умовах і соціальному середовищі [5, с. 503].

Розуміння структури, змісту професійної діяльності $є$ актуальним у сенсі розуміння професійної придатності будь-якого персоналу не лише як динамічного комплексу його психічних і психофізіологічних особливостей, ціннісно-орієнтаційних та компетентнісних, моральних якостей індивіда, але й діяльнісного потенціалу працівника до роботи, необхідні для навчання і подальшого професійного розвитку в тій або іншій професійній сфері $[15$, с. 46].

До загальновідомих факторів, таких, що впливають на процес прийняття управлінських рішень, відносять: особисті якості керівника; його поведінку; середовище прийняття рішень (визначеність та ризик); інформаційні обмеження (зростання витрат на отримання додаткової інформації); взаємозалежність рішень; готовність до можливих негативних наслідків; можливість застосування сучасних технічних засобів; наявність ефективних комунікацій; відповідність структури управління цілям та місії організації.

На базі кафедри педагогіки та психології управління соціальними системами ім. акад. І.А. Зязюна Національного технічного університету «Харківський політехнічний інститут» нами було проведено опитування серед студентів-психологів 3 курсу (в опитуванні взяли участь 45 осіб), які вже мали досвід взаємодії з керівниками у період проходження навчальних практик. Одним із запропонованих питань було завдання назвати десять топових атрибутивних рис сучасного керівника, який прагне до філософії управління (філософії мудрого управління). Відповіді, отримані нами, зацікавили не тільки своєю відвертістю, повнотою, а й сучасним поглядом молоді на роль керівника у мінливому середовищі. Так, опитувані перелічили 65 атрибутивних рис, які, на їх думку, повинен мати сучасний керівник. За частотою повторюваних атрибутивних рис відповіді респондентів визначились у таких спосіб: 20 однакових атрибутивних рис сучасного керівника відмітило $30 \%$ опитуваних; 10 однакових атрибутивних рис сучасного керівника відмітило 50\% опитуваних; менше 3 однакових атрибутивних рис сучасного керівника відмітило $40 \%$ опитуваних. 
За результатами проведеного дослідження ми виокремили 10 топових атрибутивних рис сучасного керівника, перелік яких наведено у таблиці 1.

Таблиця 1

10 топових атрибутивних рис сучасного керівника, який прагне до філософії управління

\begin{tabular}{|c|l|c|}
\hline $\begin{array}{c}\text { № } \\
\text { ח/п }\end{array}$ & Назва атрибутивної риси сучасного керівника & $\begin{array}{c}\text { Кількість опитуваних, які } \\
\text { її виокремили (осіб) }\end{array}$ \\
\hline 1 & Професіоналізм & 38 \\
\hline 2 & Чесність & 37 \\
\hline 3 & Відповідальність & 27 \\
\hline 4 & Командна робота & 27 \\
\hline 5 & Працьовитість & 26 \\
\hline 6 & Адаптивність & 25 \\
\hline 7 & Креативність & 25 \\
\hline 8 & Аналітичність & 25 \\
\hline 9 & Стресостійкість & 24 \\
\hline 10 & Лідерство & 23 \\
\hline
\end{tabular}

Що стосується 20 атрибутивних рис сучасного керівника, який прагне до філософії управління, які виокремили $30 \%$ респондентів, то половину 3 них можна додати до 10 топових рис, визначених у таблиці 1: емпатію, життєві цінності, емоційний інтелект виокремили 19 осіб; принциповість, харизму - 18 осіб; компетентність, рішучість, бачення стратегії, особисту культуру - 17 осіб; оптимізм - 16 осіб; прогностичність - 15 осіб. Чималий інтерес представляє решта атрибутивних рис сучасного керівника, яка була названа респондентами: справедливість, позитивний настрій, гумор, врівноваженість, пунктуальність, організованість, досвід, обачність, ентузіазм, завзятість, ерудиція, власна організованість, вміння вселяти до себе повагу, вміння вибудовувати відносини, спостережливість, критичне мислення, цілеспрямованість, вимогливість, толерантність, унікальність, етичне поводження, уміння домовлятися, самодисципліна, самоконтроль, вмотивованість, цілеспрямованість, тактовність, упертість, незламність, відданість справі, чуйність, самоповага, раціональність, логічність, бажання самореалізації, впевненість у собі, уважність, наполегливість, винахідливість.

Загальний аналіз опитування наведений у зведеній таблиці 2 , де умовні скорочення позначають такі атрибутивні риси сучасного керівника, який прагне до філософії управління: Ч - чесність; В - відповідальність; Л - лідерство; Ад - адаптивність; Пф - професіоналізм; Ем - емпатія; Пр - працьовитість; Х - харизма; Кр - креативність; Р - рішучість; Ко - особиста культура; Оп - оптимізм; Км - компетентність; Пг - прогностичність; Кд - командна робота; Пц - принциповість; Ан - аналітичність ; Сг - стратегічність; Жц - життєві цінності; Ст - стресостійкість. 
Таблиця 2

Загальний аналіз опитування щодо визначення атрибутивних рис сучасного керівника, який прагне до філософії управління

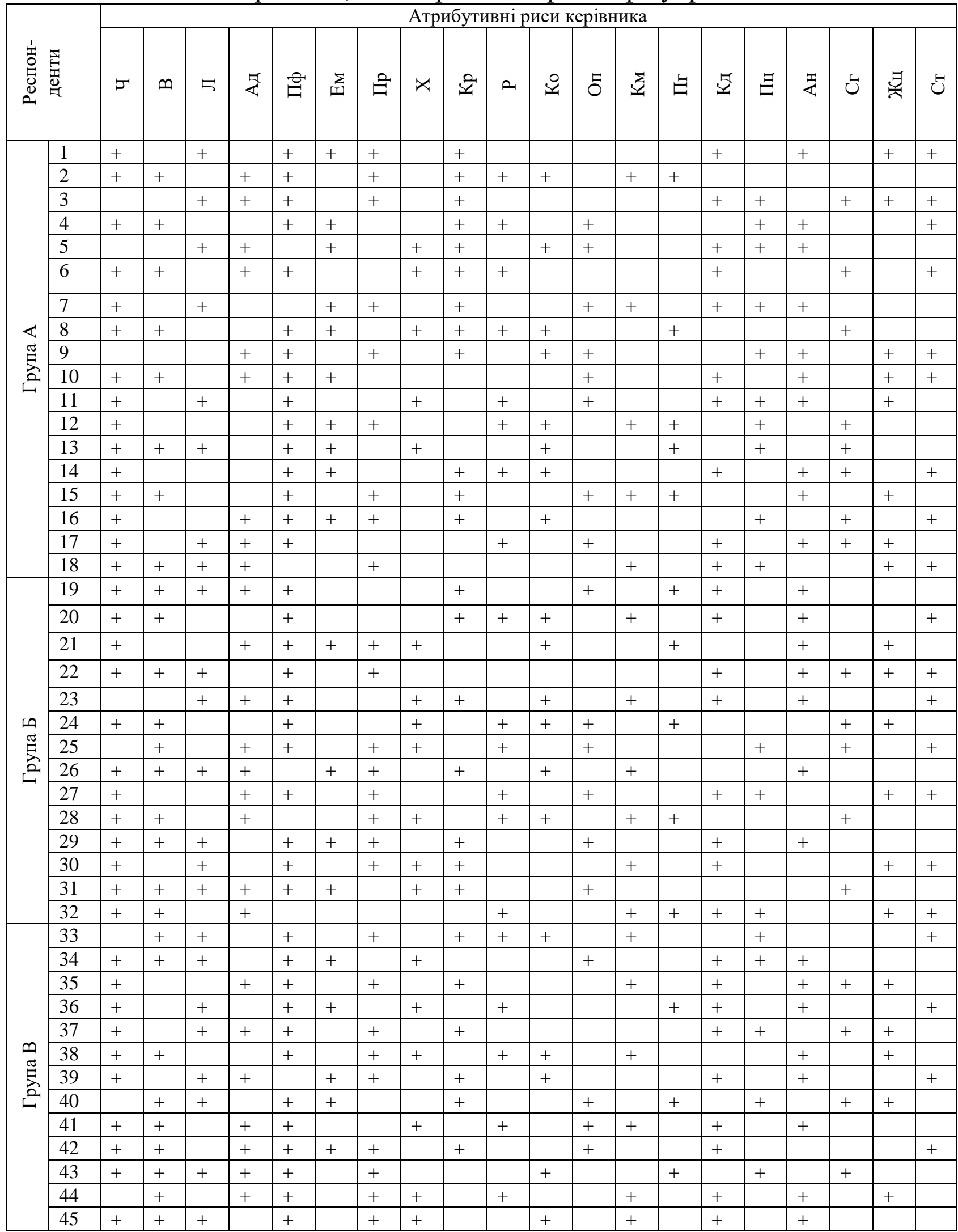


Отже, отримані результати дослідження дають підстави стверджувати, що атрибутивні риси сучасного керівника, який прагне до філософії управління, співпадають із тими вимогами, які висуває суспільство і держава щодо керівних кадрів за умов викликів часу.

Висновки. На підставі нашого дослідження щодо впливу філософськоуправлінських факторів на формування атрибутивних якостей сучасного керівника, ми можемо дійти таких висновків:

По-перше, забезпечення всіх сфер життєдіяльності держави кваліфікованими кадрами відповідає основним характеристикам кадрової політики держави (зв'язку зі стратегією, орієнтації на довгострокове планування, значущість ролі персоналу, філософії фірми відносно працівників).

По-друге, здійснювати функції управління повинні керівники, які у своій діяльності керуються мудрим управлінням і мають такі атрибутивні риси, як: професіоналізм, чесність, відповідальність, працьовитість, адаптивність, креативність, аналітичність, стресостійкість, лідерство, уміння працювати в команді.

По-третє, атрибутивні риси сучасного керівника, який прагне до філософії управління, не $є$ чимось заданим, вони мають особливість змінюватися залежно від мінливого середовища.

Перспективним, на нашу думку, є дослідження впливу філософії управління на формуванні атрибутивних рис державного службовця.

\section{Список використаних джерел:}

1. Витко Т. Ю. Державна кадрова політика України: сутність, сучасний стан і перспективи розвитку. Теорія та практика державного управління i місцевого самоврядування. 2016. URL: http://elzbirndu.at.ua/2016_1/3.pdf.

2. Гончар С. В. Механізми реалізації державної кадрової політики в Україні на регіональному та муніципальному рівнях в контексті децентралізації : дис. канд. держ. упр. : 25.00.02. Миколаїв, 2019. 263 с.

3. Грень Л. М. Проблеми саморозвитку професійно-технічної освіти в Україні: державно-управлінський аспект. Вісник Національного університету цивільного захисту України. 2020. Вип. 2 (13). С. 345-361. (Серія «Державне управління»).

4. Державна служба : підручник : у 2 т. Т.1. Нац. акад. держ. упр. при Президентові України; ред. кол. : Ю. В. Ковбасюк, О. Ю. Оболенський, С. М. Серьогін та ін. Київ, НАДУ. 2012. 372 с.

5. Державне управління : підручник : у 2 т. / Нац. акад. держ. упр. при Президентові України ; ред. кол. : Ю. В. Ковбасюк (голова), К. О. Ващенко (заст. голови), Ю. П. Сурмін (заст. голови) [та ін.]. К. ; Дніпропетровськ : НАДУ, 2012. Т. 1.564 с.

6. Диев В. С. Философия управления : проблемы, подходы, тенденции / В. С. Диев // Вестник Новосибирского государственного университета. Се- 
рия : философия. - 2011. - Т.9. - № 1. - С. 5-15.

7. Домбровська C.M. Теоретичні аспекти формування механізмів державного управління у реформуванні вищої освіти України. URL: http://www.kbuapa.kharkov.ua/e-book/db/2010-2/doc/2/01.pdf.

8. Дороніна О. А. Стратегічні завдання розбудови державної кадрової політики в Україні. Держава та регіони: Серія: Економіка та підприємництво. 2015. № 4. С. 10-17.

9. Казюк Я. Актуальні проблеми кадрової політики в галузі державного управління. URL: http://www.kbuapa.kharkov.ua/e-book/putp/20114/doc/2/02.pdf.

10. Пономарьов О.С., Чеботарьов М.К., Солодовник Т.О. Філософія управління в системі наук про управління: методичні вказівки. Харків. НТУ «ХПІ», 2020. $24 \mathrm{c}$.

11. Стратегія державної кадрової політики на 2012-2020 роки. URL: http://www.center.gov.ua/pres-tsentr/novini/item/257.

12. Тарасов С.С. Організаційно-економічний механізм державного управління формуванням кадрової політики: автореф. дис. канд. наук 3 держ. упр. - 25.00.02 механізми державного управління. Х., 2019. 23 с.

13. Філософські проблеми державного управління : навч.-метод. матеріали / авт. кол. : В. М. Князєв, Ю. В. Бакаєв, Т. Е. Василевська та ін. ; за заг. ред. В. М. Князєва. К. : НАДУ, 2012. 52 с..

14. Чеботарьов М. К. Формування готовності майбутніх менеджерів до адаптивного управління у процесі професійної підготовки: автореф. канд. пед. наук. - 13.00.04 «Теорія і методика професійної освіти. Вінниця. 2018. $21 \mathrm{c}$.

15. Шпекторенко I. В., Бородін С. І. Структура та методологія управлінської діяльності. Державне управління та місцеве самоврядування. 2018. вип. 3(38). C. 46-52. URL: http://nbuv.gov.ua/UJRN/dums_2018_3_8.

\section{References:}

1. Vytko T. YU. "State personnel policy of Ukraine: essence, current state and prospects of development [Theory and practice of public administration and local self-government]". URL: http://el-zbirndu.at.ua/2016_1/3.pdf.

2. Honchar S. V. "Mekhanizmy realizatsii derzhavnoi kadrovoi polityky v Ukraini na rehionalnomu ta munitsypalnomu rivniakh v konteksti detsentralizatsii [Mechanisms for implementing the state personnel policy in Ukraine at the regional and municipal levels in the context of decentralization]": dys. kand. derzh. upr. : 25.00.02. Mykolaiv, 2019. 263. Print.

3. Hren L.M. "Problems of self-development of vocational education in Ukraine: public administration aspect [Bulletin of the National University of Civil Defense of Ukraine]". 2020. Vyp. 2 (13). P. 345-361. Print.

4. Civil service: a textbook: u 2 t. T.1. Nats. akad. derzh. upr. pry Prezydentovi Ukrainy; red. kol. : Yu. V. Kovbasiuk, O. Yu. Obolenskyi, S. M. Serohin ta 
in. Kyiv, NADU. 2012. 372. Print.

5. Public administration: a textbook: u 2 t. / Nats. akad. derzh. upr. pry Prezydentovi Ukrainy ; red. kol. : Yu. V. Kovbasiuk (holova), K. O. Vashchenko (zast. holovy), Yu. P. Surmin (zast. holovy) [ta in.]. K. ; Dnipropetrovsk : NADU, 2012. T. 1. - 564. Print.

6. Dyev V. S. "Philosophy of management: problems, approaches, tendencies [Bulletin of Novosibirsk State University. Series: philosophy]”. 2011. T.9. № 1. P. 5-15. Print.

7. Dombrovska S.M. "Teoretychni aspekty formuvannia mekhanizmiv derzhavnoho upravlinnia u reformuvanni vyshchoi osvity Ukrainy [Theoretical aspects of the formation of mechanisms of public administration in the reform of higher education of Ukraine]". URL : http: // www.kbuapa.kharkov.ua/ebook/db/2010-2/doc/2/01.pdf.

8. Doronina O. A. "Strategic tasks of state personnel policy development in Ukraine [Country and regions: Series: Economy and Entrepreneurship]". 2015. № 4. P. 10-17. Print.

9. Kaziuk Ya. "Current problems of personnel policy in the field of public administration" [Elektronnyi resurs]. URL: http://www.kbuapa.kharkov.ua/ebook/putp/2011- 4/doc/2/02.pdf.

10. Ponomarov O.S., Chebotarov M.K., Solodovnyk T.O. Philosophy of management in the system of management sciences: guidelines. . Kharkiv. NTU «KhPI», 2020. 24. P. 14. Print.

11. Strategy of the state personnel policy for 2012-2020 [Elektronnyi resurs]. URL: http://www.center.gov.ua/pres-tsentr/novini/item/257.

12. Tarasov S.S. "Orhanizatsiino-ekonomichnyi mekhanizm derzhavnoho upravlinnia formuvanniam kadrovoi polityky [Organizational and economic mechanism of state management of personnel policy formation]" : avtoref. dys. kand. nauk z derzh. upr. - 25.00.02 mekhanizmy derzhavnoho upravlinnia. - Kh., 2019. 23. Print.

13. Philosophical problems of public administration: teaching method. materials avt. kol. : V. M. Kniaziev, Yu. V. Bakaiev, T. E. Vasylevska ta in. ; za zah. red. V. M. Kniazieva. K. : NADU, 2012. 52. Print.

14. Chebotarov M. K. "Formuvannia hotovnosti maibutnikh menedzheriv do adaptyvnoho upravlinnia u protsesi profesiinoi pidhotovky [Formation of readiness of future managers for adaptive management in the process of professional training]": avtoref. kand. ped. nauk. 13.00.04 «Teoriia i metodyka profesiinoi osvity. Vinnytsia. 2018. 21. Print.

15. Shpektorenko I. V., Borodin Ye. I. "Struktura ta metodolohiia upravlinskoi diialnosti [Structure and methodology of management]". Derzhavne upravlinnia ta mistseve samovriaduvannia. 2018. Vyp. 3(38). P. 46-52. URL: http://nbuv.gov.ua/UJRN/dums_2018_3_8. 